\title{
Synthesis and anticancer activity evaluation of new isoindole analogues
}

\author{
Aytekin Köse $^{1}$ - Yıldız Bal ${ }^{2}$ Nurhan H. Kishalı ${ }^{1}$ Gülşah Şanlı-Mohamed ${ }^{2}$. \\ Yunus Kara ${ }^{1}$
}

Received: 10 June 2016 / Accepted: 18 January 2017 / Published online: 25 January 2017

(C) Springer Science+Business Media New York 2017

\begin{abstract}
We have developed a versatile synthetic approach for the synthesis of new isoindole derivatives via the cleavage of ethers from tricyclic imide skeleton compounds. An exo-cycloadduct prepared from the Diels-Alder reaction of furan and maleic anhydride furnished imide derivatives. The epoxide ring was opened with $\mathrm{Ac}_{2} \mathrm{O}$ in the presence of a catalytic amount of $\mathrm{H}_{2} \mathrm{SO}_{4}$ in order to yield new isoindole derivatives ( $\mathbf{8 a}$ and $\mathbf{8 b}$ ). The anticancer activity of these compounds was evaluated against MCF-7 (breast adenocarcinoma) and A549 (adenocarcinomic human alveolar basal epithelial) cell lines. The synthesized compounds showed concentration- and time-dependent inhibitory effects on the viability of both cell lines. Compound 8a was more toxic compared to $\mathbf{8 b}$ in both cancer cell lines, having higher cytotoxicity against A549 cells. Testing the toxicity properties of these compounds on the BEAS 2B (human bronchial epithelial) cell line indicated that while both compounds decreased the cell viability of cancer cells, they were less toxic on healthy lung cells. Microscopy images of A549 cells after treatment with the new isoindole derivatives displayed characteristic apoptotic
\end{abstract}

Electronic supplementary material The online version of this article (doi:10.1007/s00044-017-1793-1) contains supplementary material, which is available to authorized users.

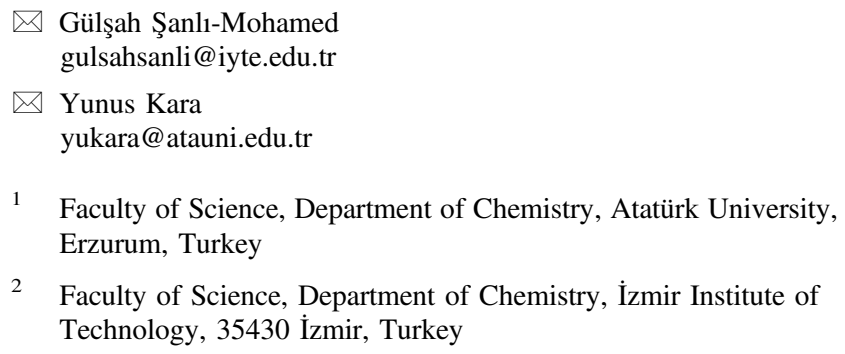

1 Faculty of Science, Department of Chemistry, Atatürk University, Erzurum, Turkey

2 Faculty of Science, Department of Chemistry, İzmir Institute of Technology, 35430 İzmir, Turkey

morphology compared to BEAS 2B cells. The results demonstrated here suggest that these new compounds might be considered as possible potential anticancer agents for the treatment of lung and breast cancer.

Keywords Isoindole $\cdot$ Norcantharimide $\cdot$ Ether cleavage $\cdot$ Anticancer $\cdot$ Cytotoxicity $\cdot$ Cancer cell lines

\section{Introduction}

Norcantharidin (2) and norcantharimide (3), which are derivatives of cantharidin (1), have attracted considerable attention due to their potential anticancer effects (Fig. 1). Cantharidin (1), a natural compound has been known to be an anticancer agent since 13th century. (Nicholls and Teare 1954; Wang 1989; Lin et al. 1998). Because of its substantial toxicity (Tagwireyi et al. 2000), it is not used in chemotherapeutical studies. Norcantharidin and norcantharimide have lower toxicity and are known as anticancer agents (Hill et al. 2007). Cantharidin and its analogs have been found to have inhibitory effects against protein phosphatase 1 and 2A (PP1 and PP2A) (Li and Casida 1992; Li et al. 1993; Honkanen 1993; Sodeoka et al. 1997). The anticancer activity of cantharidin (1) and norcantharidin (2) is thought to come from the inhibition of protein phosphatase 1 and 2A (Fig. 1). Recently, scientists have revealed the connection between its protein phosphatase inhibitor and anticancer activity (McCluskey et al. 2000, 2001, 2003; Sakoff et al. 2002; Hart et al. 2004).

In recent years, much effort has been devoted to the synthesis of $\mathrm{N}$-derivatives of norcantharimide (Robertson et al. 2011). Some of the synthesized norcantharimide 
Fig. 1 Structure of cantharidin (1), norcantharidin (2), and norcantharimide (3)

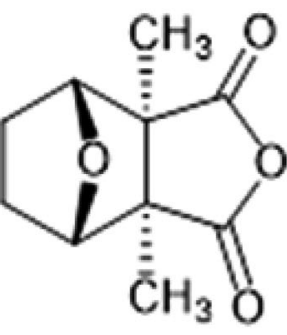

1

\section{Cantharidin}

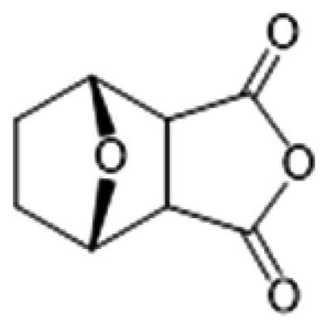

2

\section{Norcantharidin}

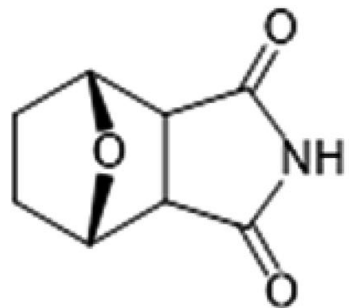

3

\section{Norcantharimide}

derivatives had an effect on a number of types of cancer (Robertson et al. 2011). For example, the tumor-inhibitory action of $N$-methylcantharimide has been established in animals. McCluskey et al. (2003) synthesized various norcantharimides and investigated their cytotoxicity against different carcinomas. They investigated the effects of subtle skeletal modifications on the anticancer activity of the compounds. Lin et al. (2000, 2004) also reported the synthesis and anticancer activity of the $N$-substituted cantharimides (aliphatic, aryl, and pyridyl groups) in vitro against HepG2 and HL-60 cells. Kok et al. (2007) studied the synthesis and cytotoxicity of some cantharimide derivatives. They thoroughly explored electronic properties of the functional group on the cytotoxicity of some cantharimide derivatives (Kok et al. 2007).

Recently, we reported a versatile synthetic approach to the synthesis of new norcantharimide or isoindole derivatives (Tan et al. 2011). We investigated the fluorescence properties of some of these norcantharimide derivatives (Tan et al. 2014). In this work, new isoindole derivatives were synthesized and their antiproliferative properties were examined on the MCF-7 (breast adenocarcinoma) and A549 (adenocarcinoma human alveolar basal epithelial) cell lines. The toxicity of the compounds was also examined on the healthy lung cell line BEAS 2B (human bronchial epithelial cells). New isoindole derivatives were found to be potential anticancer agents for the treatment of various cancer types.

\section{Experimental}

\section{Chemistry part}

All reagents used were commercially available unless otherwise specified and all solvents were distilled before use. Melting points were measured with Gallenkamp melting point devices. ${ }^{1} \mathrm{H}$ and ${ }^{13} \mathrm{C}$ NMR spectra were recorded on Varian 400 and Bruker 400 spectrometers. Elemental analysis results were obtained with a LECO CHNS-932 instrument.
Synthesis of (3aR,4S,7R,7aS)-3a,4,7,7a-tetrahydro-4,7epoxyisobenzofuran-1,3-dione (6)

In a $250-\mathrm{mL}$ three-necked round-bottom flask under argon atmosphere, maleic anhydride $(5.0 \mathrm{~g}, 50.99 \mathrm{mmol})$ and furan $(5.2 \mathrm{~g}, 76.5 \mathrm{mmol})$ were dissolved in $30 \mathrm{~mL}$ of toluene. The mixture was stirred for $24 \mathrm{~h}$ of heating under reflux. A white precipitate formed during this time. The solid was collected by filtration and washed two times with cold diethyl ether. The filtrate was reduced by rotary evaporation and crystallized from $\mathrm{MeOH} /$ diethyl ether. Yield: colorless crystals, $8.22 \mathrm{~g}(97 \%)$.

${ }^{1} \mathrm{H}$ NMR (400 MHz, $\left.\mathrm{CDCl}_{3}, 25^{\circ} \mathrm{C}\right) \delta=6.57\left(\mathrm{~s}, 2 \mathrm{H}, \mathrm{H}_{5}\right.$, $\left.\mathrm{H}_{6}\right), 5.45$ (s, 2H, $\left.\mathrm{H}_{4}, \mathrm{H}_{7}\right), 3.18\left(\mathrm{~s}, 2 \mathrm{H}, \mathrm{H}_{3 \mathrm{a}}, \mathrm{H}_{7 \mathrm{a}}\right) .{ }^{13} \mathrm{C} \mathrm{NMR}$ $\left(100 \mathrm{MHz}, \mathrm{CDCl}_{3}, 25^{\circ} \mathrm{C}\right) \delta=170.1(2 \mathrm{C}=\mathrm{O}), 137.2\left(\mathrm{C}_{5}\right.$, $\left.\mathrm{C}_{6}\right), 82.4\left(\mathrm{C}_{4}, \mathrm{C}_{7}\right), 48.9\left(\mathrm{C}_{3 \mathrm{a}}, \mathrm{C}_{7 \mathrm{a}}\right)$.

Synthesis of 2-((3aR,4S,7R,7aS)-1,3-dioxo-1,3,3a,4,7,7ahexahydro-2H-4,7-epoxyisoindol-2-yl)ethyl acetate (7a)

To a $100-\mathrm{mL}$ round-bottom flask with a magnetic stir bar and reflux condenser was added 3a,4,7,7a-tetrahydro-4,7epoxyisobenzofuran-1,3-dione (6) $(1.50 \mathrm{~g}, 9.03 \mathrm{mmol})$ followed by $\mathrm{MeOH}(15 \mathrm{~mL})$ and ethanolamine $(0.55 \mathrm{~g}, 9.03$ mmol). The solution turned dark orange and was brought to reflux for $24 \mathrm{~h}$. The flask was cooled to room temperature, and after $2 \mathrm{~h}$ the product began to crystallize. The mixture was stored in a freezer overnight and the precipitate was collected by vacuum filtration. Yield: $1.0 \mathrm{~g}(53 \%)$ as a white solid (Heath et al. 2008). This alcohol was then submitted to acetylation. For the acetylation, to a magnetically stirred solution of crude product (290 $\mathrm{mg}, 1.27 \mathrm{mmol}$ ) in $\mathrm{CH}_{2} \mathrm{Cl}_{2}$ (1 mL) was added acetyl chloride $(521 \mathrm{mg}, 5.1 \mathrm{mmol})$. The mixture was stirred at r.t. for $6 \mathrm{~h}$. Removal of the solvent, $\mathrm{HCl}$, and excess acetyl chloride under reduced pressure gave sole product acetate $\mathbf{7 a}$ as colorless crystals (M.p: 92-94 $\left.{ }^{\circ} \mathrm{C}\right)$.

${ }^{1} \mathrm{H}$ NMR (400 MHz, $\left.\mathrm{CDCl}_{3}, 25{ }^{\circ} \mathrm{C}\right) \delta=6.47\left(\mathrm{~s}, 2 \mathrm{H}, \mathrm{H}_{5}\right.$, $\left.\mathrm{H}_{6}\right), 5.21\left(\mathrm{~s}, 2 \mathrm{H}, \mathrm{H}_{4}, \mathrm{H}_{7}\right), 4.16\left(\mathrm{t}, 2 \mathrm{H}, \mathrm{H}_{9}, J=5.4 \mathrm{~Hz}\right), 3.69$ (t, $\left.2 \mathrm{H}, \mathrm{H}_{8}, J=5.4 \mathrm{~Hz}\right), 2.83\left(\mathrm{~s}, 2 \mathrm{H}, \mathrm{H}_{3 \mathrm{a}}, \mathrm{H}_{7 \mathrm{a}}\right), 1.95(\mathrm{~s}, 3 \mathrm{H}$, 
OAc). ${ }^{13} \mathrm{C}$ NMR $\left(100 \mathrm{MHz}, \mathrm{CDCl}_{3}, 25^{\circ} \mathrm{C}\right) \quad \delta=176.2$ $(2 \mathrm{C}=\mathrm{O}$ of imide $), 171.0(\mathrm{C}=\mathrm{O}$ of acetate $), 136.8\left(\mathrm{C}_{5}, \mathrm{C}_{6}\right)$, $81.1\left(\mathrm{C}_{4}, \mathrm{C}_{7}\right), 60.7\left(\mathrm{C}_{9}\right), 47.6\left(\mathrm{C}_{3 \mathrm{a}}, \mathrm{C}_{7 \mathrm{a}}\right), 38.0\left(\mathrm{C}_{8}\right), 20.9$ $\left(\mathrm{CH}_{3}\right)$. Anal. calcd. for $\mathrm{C}_{12} \mathrm{H}_{13} \mathrm{NO}_{5}$ : C 57.37; $\mathrm{H} 5.22 ; \mathrm{N}$ 5.58. Found: C 57.29; H 5.13; N 5.41.

Synthesis of (3aR,4S, 7R,7aS)-2-methyl-3a,4,7,7atetrahydro-1H-4,7-epoxyisoindole-1,3(2H)-dione (7b)

To a 100-mL round-bottom flask with a magnetic stir bar and reflux condenser was added 3a,4,7,7a-tetrahydro-4,7epoxyisobenzofuran-1,3-dione (6) $(5.0 \mathrm{~g}, 30.1 \mathrm{mmol})$ followed by $\mathrm{MeOH}(30 \mathrm{~mL})$ and methylamine (3.74 g, 120.4 mmol). The mixture was refluxed for $24 \mathrm{~h}$. The $\mathrm{MeOH}$ was removed by rotary evaporation, and the crude product was crystallized from $\mathrm{CH}_{2} \mathrm{Cl}_{2}$ /hexane. The crystals were collected by filtration. Reducing the filtrate and recrystallizing again provided a second crop. Yield: colorless crystals (M. p: $\left.138-140^{\circ} \mathrm{C}\right), 4.48 \mathrm{~g}(83 \%)$.

${ }^{1} \mathrm{H}$ NMR $\left(400 \mathrm{MHz}, \mathrm{CDCl}_{3}, 25{ }^{\circ} \mathrm{C}\right) \delta=6.49\left(\mathrm{~m}, 2 \mathrm{H}, \mathrm{H}_{5}\right.$, $\left.\mathrm{H}_{6}\right), 5.24\left(\mathrm{~m}, 2 \mathrm{H}, \mathrm{H}_{4}, \mathrm{H}_{7}\right), 2.94\left(\mathrm{~s}, 3 \mathrm{H}, \mathrm{CH}_{3}\right), 2.83(\mathrm{~s}, 2 \mathrm{H}$, $\left.\mathrm{H}_{3 \mathrm{a}}, \mathrm{H}_{7 \mathrm{a}}\right) .{ }^{13} \mathrm{C} \mathrm{NMR}\left(100 \mathrm{MHz}, \mathrm{CDCl}_{3}, 25^{\circ} \mathrm{C}\right) \delta=176.5$ $\left(2 \times \mathrm{CO}\right.$ of imide), $136.7\left(\mathrm{C}_{5}, \mathrm{C}_{6}\right), 81.0\left(\mathrm{C}_{4}, \mathrm{C}_{7}\right), 47.7\left(\mathrm{C}_{3 \mathrm{a}}\right.$, $\left.\mathrm{C}_{7 \mathrm{a}}\right), 25.1\left(\mathrm{CH}_{3}\right)$. Anal. calcd. for $\mathrm{C}_{9} \mathrm{H}_{9} \mathrm{NO}_{3}: \mathrm{C}(60.33), \mathrm{H}$ (5.06), N (7.82). Found: C (60.68), H (4.91), N (7.66).

Acid-catalyzed acetolysis of 7 with $\mathrm{Ac}_{2} \mathrm{O}$

Norcantharimide derivative $7 \mathbf{a}(2.3 \mathrm{~g}, 9.15 \mathrm{mmol})$ was dissolved in $\mathrm{Ac}_{2} \mathrm{O}(5 \mathrm{~mL})$. After the addition of three drops of $\mathrm{H}_{2} \mathrm{SO}_{4}$ the reaction mixture was magnetically stirred at room temperature for 2 days. $\mathrm{Ac}_{2} \mathrm{O}$ was removed under reduced pressure. The crude product was recrystallized from $\mathrm{CH}_{2} \mathrm{Cl}_{2}$ /hexane. Yield (8a): white powder (M.p: $111-113{ }^{\circ} \mathrm{C}$ ), $2.15 \mathrm{~g}(66 \%)$. The same procedure was applied to $0.116 \mathrm{~g}$ $(0.65 \mathrm{mmol})$ of $\mathbf{7 b}$ in $3 \mathrm{~mL}$ of $\mathrm{Ac}_{2} \mathrm{O}$ for $24 \mathrm{~h}$. Compound $\mathbf{8 b}$ was obtained as colorless crystals (M.p: $135-137^{\circ} \mathrm{C}$ ). Yield: $0.15 \mathrm{~g}(82 \%)$.

(3aR,4R,7R, 7aS)-2-(2-acetoxyethyl)-1,3-dioxo-2,3,3a,4,7,7ahexahydro-1H-isoindole-4,7-diyl diacetate $(8 \mathrm{~B})$

${ }^{1} \mathrm{H}$ NMR $\left(400 \mathrm{MHz}, \mathrm{CDCl}_{3}, 25^{\circ} \mathrm{C}\right) \delta=6.25\left(\mathrm{~d}, 1 \mathrm{H}, \mathrm{H}_{6}, J\right.$ $=10.0 \mathrm{~Hz}), 6.00\left(\mathrm{~m}, 1 \mathrm{H}, \mathrm{H}_{5}\right), 5.34\left(\mathrm{bs}, 1 \mathrm{H}, \mathrm{H}_{7}\right), 5.17(\mathrm{t}, 1 \mathrm{H}$, $\left.\mathrm{H}_{4}, J=4.8 \mathrm{~Hz}\right), 4.15\left(\mathrm{~m}, \mathrm{~A}\right.$ of $\left.\mathrm{AB}, 1 \mathrm{H}, \mathrm{H}_{9 \mathrm{a}}\right), 4.11(\mathrm{~m}, \mathrm{~B}$ of $\left.\mathrm{AB}, 1 \mathrm{H}, \mathrm{H}_{9 \mathrm{~b}}\right), 3.71\left(\mathrm{~m}, 2 \mathrm{H}, \mathrm{H}_{8}\right), 3.48\left(\mathrm{~m}, 2 \mathrm{H}, \mathrm{H}_{3 \mathrm{a}}, \mathrm{H}_{7 \mathrm{a}}\right)$, 2.01 (s, 3H, OAc), 1.94 (s, 3H, OAc), 1.92 (s, 3H, OAc). ${ }^{13} \mathrm{C}$ NMR $\left(100 \mathrm{MHz}, \mathrm{CDCl}_{3}, 25^{\circ} \mathrm{C}\right) \delta=175.3\left(\mathrm{C}_{3}\right), 175.0$ $\left(\mathrm{C}_{1}\right), \quad 171.0 \quad\left(\mathrm{NCH}_{2} \mathrm{CH}_{2} \mathrm{OAc}\right), \quad 169.6 \quad\left(\mathrm{C}_{4} \mathrm{OAc}\right), 169.3$ $\left(\mathrm{C}_{7} \mathrm{OAc}\right), 126.5\left(\mathrm{C}_{6}\right), 125.2\left(\mathrm{C}_{5}\right), 66.8\left(\mathrm{C}_{7}\right), 64.1\left(\mathrm{C}_{4}\right), 61.1$ $\left(\mathrm{C}_{9}\right), 39.9\left(\mathrm{C}_{7 \mathrm{a}}\right), 39.4\left(\mathrm{C}_{3 \mathrm{a}}\right), 38.1\left(\mathrm{C}_{8}\right), 21.0\left(\mathrm{COCH}_{3}\right), 20.9$ $\left(\mathrm{COCH}_{3}\right), 20.8\left(\mathrm{COCH}_{3}\right)$. Anal. calcd. for $\mathrm{C}_{16} \overline{\mathrm{H}}_{19} \mathrm{NO}_{8}: \mathrm{C}$ 54.39; H 5.42; N 3.96. Found: C 54.13; H 5.13; N 4.00.
(3aR,4R,7R,7aS)-2-methyl-1,3-dioxo-2,3,3a,4,7,7ahexahydro-1H-isoindole-4,7-diyl diacetate $(\mathbf{8 b})$

${ }^{1} \mathrm{H}$ NMR $\left(400 \mathrm{MHz}, \mathrm{CDCl}_{3}, 25^{\circ} \mathrm{C}\right) \delta=6.26\left(\mathrm{~d}, 1 \mathrm{H}, \mathrm{H}_{6}, J\right.$ $=10.0 \mathrm{~Hz}), 6.01\left(\mathrm{~m}, 1 \mathrm{H}, \mathrm{H}_{5}\right), 5.34\left(\mathrm{~m}, 1 \mathrm{H}, \mathrm{H}_{7}\right), 5.16(\mathrm{t}, 1 \mathrm{H}$, $\left.\mathrm{H}_{4}, J=4.8 \mathrm{~Hz}\right), 3.49$ (bs, 2H, H $\left.3 \mathrm{a}, \mathrm{H}_{7 \mathrm{a}}\right), 2.96$ (s, 3H, N$\mathrm{CH}_{3}$ ), 2.03 (s, 3H, C $-\mathrm{OAc}$ ), 1.91 (s, 3H, C $\left.4-\mathrm{OAc}\right) .{ }^{13} \mathrm{C}$ NMR (100 MHz, $\mathrm{CDCl}_{3}, \overline{\left.25^{\circ} \mathrm{C}\right)} \delta=175.5\left(\mathrm{C}_{1}\right), 175.2\left(\mathrm{C}_{3}\right)$, $169.6\left(\mathrm{C}_{4} \mathrm{OAc}\right), 169.3\left(\mathrm{C}_{7} \mathrm{OAc}\right), 126.7\left(\mathrm{C}_{6}\right), 125.2\left(\mathrm{C}_{5}\right)$, $67.0\left(\mathrm{C}_{7}\right), \overline{64.3}\left(\mathrm{C}_{4}\right), 40.0 \overline{\left(\mathrm{C}_{7 \mathrm{a}}\right)}, 39.6\left(\mathrm{C}_{3 \mathrm{a}}\right), 25.1\left(\mathrm{NCH}_{3}\right)$, $21.0\left(\mathrm{COCH}_{3}\right), 20.8\left(\mathrm{COCH}_{3}\right)$. Anal. calcd. for $\mathrm{C}_{16} \mathrm{H}_{19} \mathrm{NO}_{8}$ : C 55.51; $\mathrm{H} 5.38$; N 4.98. Found: C 55.19; H 5.29; N 5.00.

\section{Biological part}

\section{Cell cultures}

The MCF-7 (Michigan Cancer Foundation-7 breast adenocarcinoma) cell line, A549 (adenocarcinoma human alveolar basal epithelial) cell line, and BEAS 2B (human bronchial epithelial) cell line were kindly provided by the Biotechnology and Bioengineering Research and Application Center, Izmir Institute of Technology, Turkey. The breast cancer cells were grown in Dulbecco's modified Eagle's medium supplemented with $5 \%$ fetal bovine serum (FBS) and 1\% gentamicin sulfate, and lung cancer and healthy cells were grown in Roswell Park Memorial Institute-1640 growth medium containing $10 \% \mathrm{FBS}$ and $1 \%$ gentamicin sulfate at $37^{\circ} \mathrm{C}$ in $5 \% \quad \mathrm{CO}_{2}$. Medium was refreshed every 3 days for each cell culture. Typically, cells were passaged by trypsinization and in growth medium. Compounds $\mathbf{8 a}$ and $\mathbf{8 b}$ were dissolved in dimethyl sulfoxide (DMSO) before all analyses.

\section{Cell viability assays}

The cytotoxicities of the synthesized norcantharimide derivatives (compounds $\mathbf{8 a}$ and $\mathbf{8 b}$ ) were evaluated against the MCF-7, A549, and BEAS 2B cell lines using the MTT (3(4,5-dimethylthiazol-2-yl)-2,5-diphenyltetrazolium bromide) proliferation assay as a fast and sensitive quantification of cell proliferation and viability. MTT, a yellow tetrazole, is reduced to purple formazan in a living cell's mitochondria by mitochondrial dehydrogenases of the viable cell (Mosmann 1983). This reduction only occurs if mitochondrial reductase enzymes are active; thus, conversion is directly related to the number of viable cells. Briefly, MCF-7, A549, and BEAS 2B cells were seeded onto 96well microassay plates at a density of $1 \times 10^{4}$ cells $/ \mathrm{cm}^{2}$ and incubated at $37^{\circ} \mathrm{C}$ in $95 \%$ air, $5 \% \mathrm{CO}_{2}$ environments for 24 h. Synthesized compounds $\mathbf{8 a}$ and $\mathbf{8 b}$ were added in various concentrations $(0-250 \mu \mathrm{g} / \mathrm{mL})$ and incubated for 24,48 , and 
$72 \mathrm{~h}$. Untreated cells were used as a control group. After incubation, the medium was removed and replaced with MTT-containing medium. Plates were incubated for an additional $4 \mathrm{~h}$ at $37^{\circ} \mathrm{C}$. MTT medium was removed and $100 \mu \mathrm{L}$ of DMSO was added to dissolve the formazan crystal. The absorbance was determined using a plate reader at a wavelength of $540 \mathrm{~nm}$. Each experiment was assayed three times in triplicate. Cytotoxicity assessments of compounds 8a and 8b on MCF-7, A549, and BEAS 2B cells were represented as percentage of metabolically active cells and metabolic activity under standard growth conditions was considered as $100 \%$.

For the visual comparison of cancer and healthy cells treated with the synthesized norcantharimide derivatives (compounds 8a and $\mathbf{8 b}$ ), optical microscopy was used. For this purpose, BEAS $2 \mathrm{~B}$ and A549 cells were inoculated in 96-well plates at a density of $1 \times 10^{4}$ cells $/ \mathrm{cm}^{2}$ and incubated overnight at $37^{\circ} \mathrm{C}, 5 \% \mathrm{CO}_{2}$, and $95 \%$ relative humidity. After waiting overnight, compounds $\mathbf{8 a}$ and $\mathbf{8 b}$ were added to wells of each cell line separately at a concentration of $10 \mu \mathrm{g} / \mathrm{mL}$ and incubated for $24 \mathrm{~h}$. A control group of cells that were not treated with either of the compounds was also prepared. After incubation, they were examined using optical microscopy (Olympus CKX41, Tokyo, Japan).

\section{Results and discussion}

\section{Chemistry}

Norcantharimide derivatives have an isoindole-1,3-dione skeleton structure. To obtain new isoindole or norcantharimide derivatives, different functional groups can be attached to the imide nitrogen or cyclohexane ring. In this study, we first attempted to synthesize new isoindole derivatives via the cleavage of ethers from tricyclic imide compounds. For this purpose, the key compound 3a,4,7,7atetrahydro-4,7-epoxyisobenzofuran-1,3-dione was used. We then explored the biological evaluation of this new series of isoindole derivatives in vitro.

The key compound used in this work, 3a,4,7,7a-tetrahydro-4,7-epoxyisobenzofuran-1,3-dione (6), was prepared via an exo-selective cycloaddition of furan to maleic anhydride (Sodeoka et al. 1997; Goh et al. 2008). Condensation of the appropriate primer amine (2-aminoethanol or methylamine) with 3,6-3a,4,7,7a-tetrahydro-4,7-epoxyisobenzofuran-1,3-dione (6) in the presence of $\mathrm{CH}_{2} \mathrm{Cl}_{2}$ gave the corresponding imide in good yield (Fig. 2) (Tan et al. 2011, 2014). With the use of two different primary amines in the same reaction conditions, we were able to obtain compounds $\mathbf{7 a}$ and $\mathbf{7 b}$ (Scheme 1).
Treatment of tricyclic imide $\mathbf{7 a}-\mathbf{b}$ with acetic anhydride in the presence of $\mathrm{H}_{2} \mathrm{SO}_{4}$ at room temperature gave the trans-diacetate derivative of norcantharimide $\mathbf{8 a}-\mathbf{b}$ as a sole product in 66 and $82 \%$ yield, respectively. In this reaction, the etheric bond is stereospecifically cleaved to give transdiacetate (8a or 8b) (Baran et al. 2003; Kose et al. 2013). Compounds were purified by crystallization from $\mathrm{CH}_{2} \mathrm{Cl}_{2} /$ hexane.

\section{Biological evaluation}

In view of the anticancer activity and potential clinical use of both synthesized isoindole derivatives $(\mathbf{8} \mathbf{a}$ and $\mathbf{8 b}$ ), the cytotoxic properties of $\mathbf{8 a}$ and $\mathbf{8 b}$ were evaluated by MTT (3-(4,5-dimethylthiazol-2-yl)-2,5-diphenyltetrazolium bromide) test on two cancer cell lines (MCF-7: human breast adenocarcinoma; A549: human alveolar basal epithelial adenocarcinoma) and one healthy cell line (BEAS 2B: human bronchial epithelial cells). The MTT test is a colorimetric assay for assessing the tested cell viability in which MTT, a yellow tetrazolium, is reduced to purple formazan by mitochondrial dehydrogenases in living cells. Therefore, quantification of the metabolic activity of MCF7, A549, and BEAS 2B cells in the presence of various concentrations $(0.5,2,10,50$, and $250 \mu \mathrm{g} / \mathrm{mL})$ of compounds $8 \mathbf{a}$ and $\mathbf{8 b}$ was obtained by spectrophotometer for 24,48 , and 72 h. It was observed that, when compounds $8 \mathbf{a}$ and 8b were applied to MCF-7 and A549 cells, the cell viability of both cancer cell lines decreased with the increase in both compound concentrations in a concentration-dependent manner (Fig. 2).

Although both synthesized compounds showed concentration-dependent inhibitory effects on the viability of both cell lines, compound $\mathbf{8 a}$ had slightly better antiproliferative activity compared to $\mathbf{8 b}$ on the tested cell lines. After $24 \mathrm{~h}$, cells treated with compound 8a had approximately $39 \%$ metabolic activity at a compound concentration of $50 \mu \mathrm{g} / \mathrm{mL}$ for A549 and 55\% for MCF-7 cells. However, cells treated with compound $\mathbf{8 b}$ had metabolic activity of $53 \%$ for A549 and 64\% for MCF-7 cells after $24 \mathrm{~h}$ at a compound concentration of $50 \mu \mathrm{g} / \mathrm{mL}$. It was also observed that when the incubation time was increased up to $72 \mathrm{~h}$, the cytotoxicity of both compounds increased for both cancer cell lines. Moreover, comparison of the metabolic activity of A549 and MCF-7 cancer cells in the presence of the newly isoindole compounds showed that compounds $\mathbf{8 a}$ and 8b displayed better cytotoxic effects on A549 cells compared to MCF-7 cells (Fig. 2). After $72 \mathrm{~h}$, MCF-7 cells treated with compound $\mathbf{8 a}$ at $50 \mu \mathrm{g} / \mathrm{mL}$ had approximately $14 \%$ metabolic activity, and those treated with compound $\mathbf{8 b}$ at $50 \mu \mathrm{g} / \mathrm{ml}$ had approximately $33 \%$ metabolic activity. Under the same conditions, metabolic activity of A549 cells was $5 \%$ for compound $\mathbf{8 a}$ and $13 \%$ for compound $\mathbf{8 b}$. 

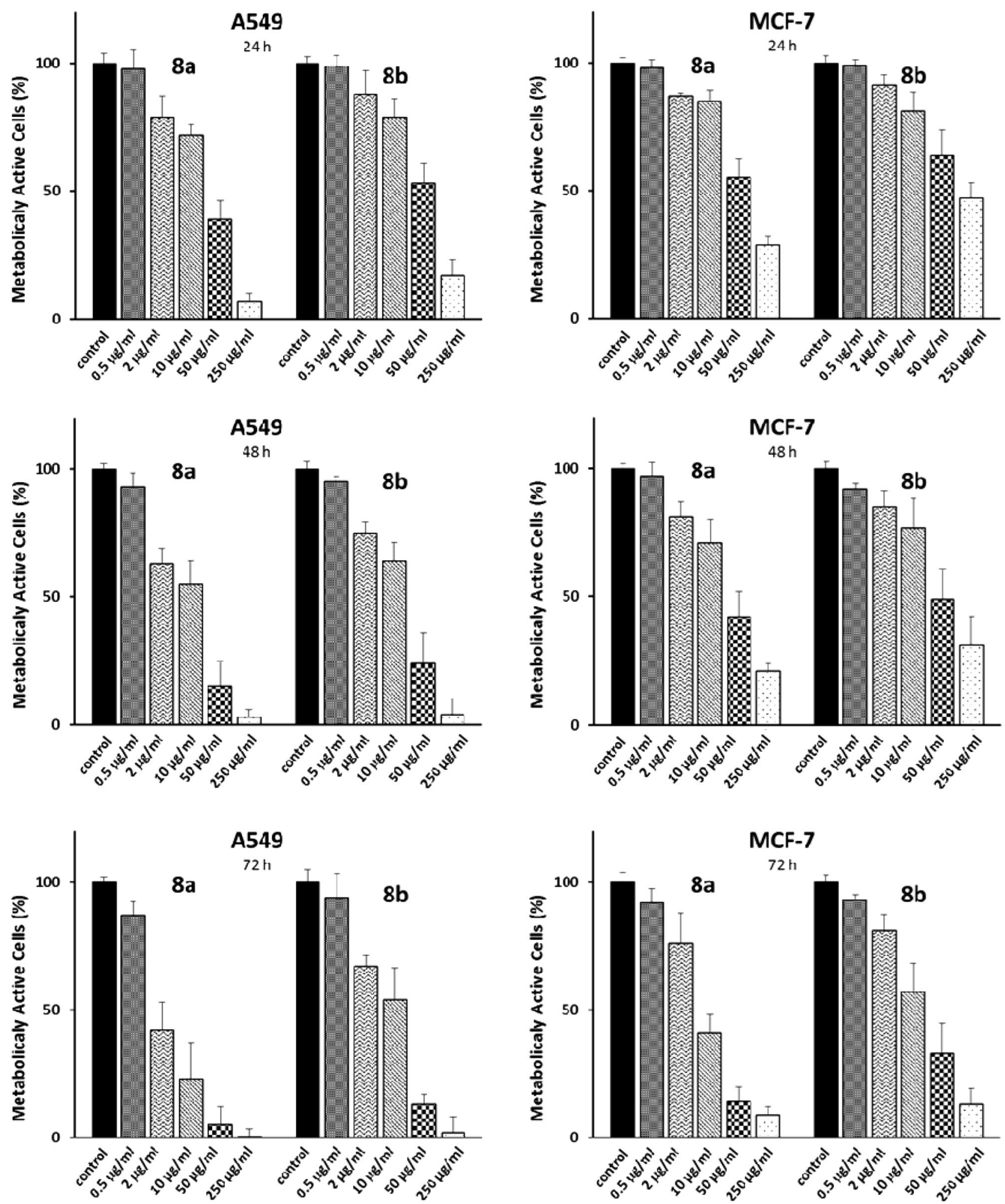

Fig. 2 Cell viability of A549 and MCF-7 cells after the treatment with compound $\mathbf{8 a}$ and $\mathbf{8 b}$ for 24, 48, and $72 \mathrm{~h}$

The cytotoxicities of compounds $\mathbf{8 a}$ and $\mathbf{8 b}$ were also tested on a healthy lung cell line, BEAS $2 \mathrm{~B}$, and the results were compared with the lung cancer cell line A549 treated with compounds 8a and $\mathbf{8 b}$ (Fig. 3).
Both synthesized compounds showed concentrationdependent inhibitory effects on the viability of BEAS 2B cells, but in comparison to A549 cells, the metabolic activity of BEAS $2 \mathrm{~B}$ was better when treated with both 
Scheme 1 . Synthesis and conditions of compounds $6-8$
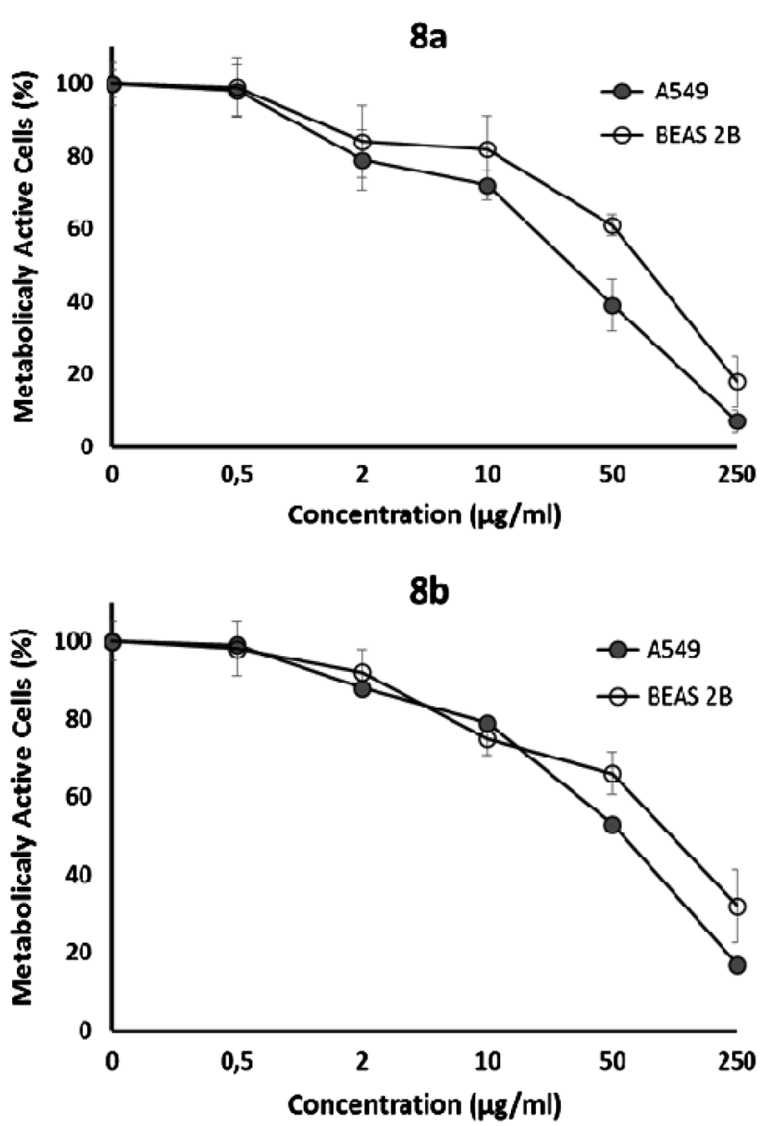

Fig. 3 Cytotoxicity assessments of compound $\mathbf{8 a}$ and $\mathbf{8 b}$ on A549 and BEAS $2 \mathrm{~B}$ cells represented as percentage metabolically active cells versus compound concentration for $24 \mathrm{~h}$<smiles>O=C1OC(=O)[C@H]2[C@H]3C=C[C@@H](O3)[C@H]12</smiles>

6

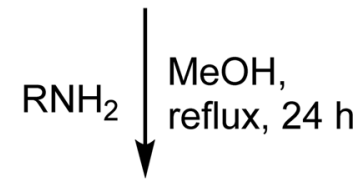<smiles></smiles>
8a $\mathrm{R}=\mathrm{CH}_{2} \mathrm{CH}_{2} \mathrm{OAC}$
8b $\quad \mathrm{R}=\mathrm{CH}_{3}$<smiles>[R]C1NC(=O)[C@@H]2[C@@H]1[C@@H]1C=C[C@H]2O1</smiles>

7a $\mathrm{R}=\mathrm{CH}_{2} \mathrm{CH}_{2} \mathrm{OAC}$

7b $\mathrm{R}=\mathrm{CH}_{3}$ compounds, 8a and $\mathbf{8 b}$. After $24 \mathrm{~h}$, BEAS 2B cells treated with compounds $\mathbf{8 a}$ and $\mathbf{8 b}$ had approximately 61 and $66 \%$ metabolic activity, respectively, at a compound concentration of $50 \mu \mathrm{g} / \mathrm{mL}$. However, under the same conditions, the metabolic activity of A549 cells was $39 \%$ with compound $\mathbf{8 a}$ and $53 \%$ with compound $\mathbf{8 b}$. These findings show that the newly synthesized isoindole derivatives $(\mathbf{8 a}$ and $\mathbf{8 b})$ have more cytotoxic effects on cancer cells in comparison to healthy cells and therefore they could be considered as new candidate anticancer agents in medicine.

For the visual comparison of cancer (A549) and healthy (BEAS 2B) cells treated with the newly synthesized isoindole derivatives (compounds $\mathbf{8 a}$ and $\mathbf{8 b}$ ), optical microscopy was used (Fig. 4). It was observed that A549 cells treated with compounds $\mathbf{8 a}$ and $\mathbf{8 b}$ were highly damaged and the number of whole cells was fewer compared to BEAS 2B cells. After treatment with a $10 \mu \mathrm{g} / \mathrm{mL}$ concentration of compounds 8a and $\mathbf{8 b}$ for $24 \mathrm{~h}$ of incubation at $37^{\circ} \mathrm{C}, \mathbf{8 a}$ treated cells of the A549 line showed more characteristics of apoptotic morphology compared to $\mathbf{8 b}$ treated A549 cells. The observed images were consistent with the results of cytotoxicity of compounds 8a and $\mathbf{8 b}$ on A549 and BEAS 2B cells.

\section{Conclusion}

As can be seen from the data presented, subtle modifications of norcantharimide skeleton permitted the development of a 
Control
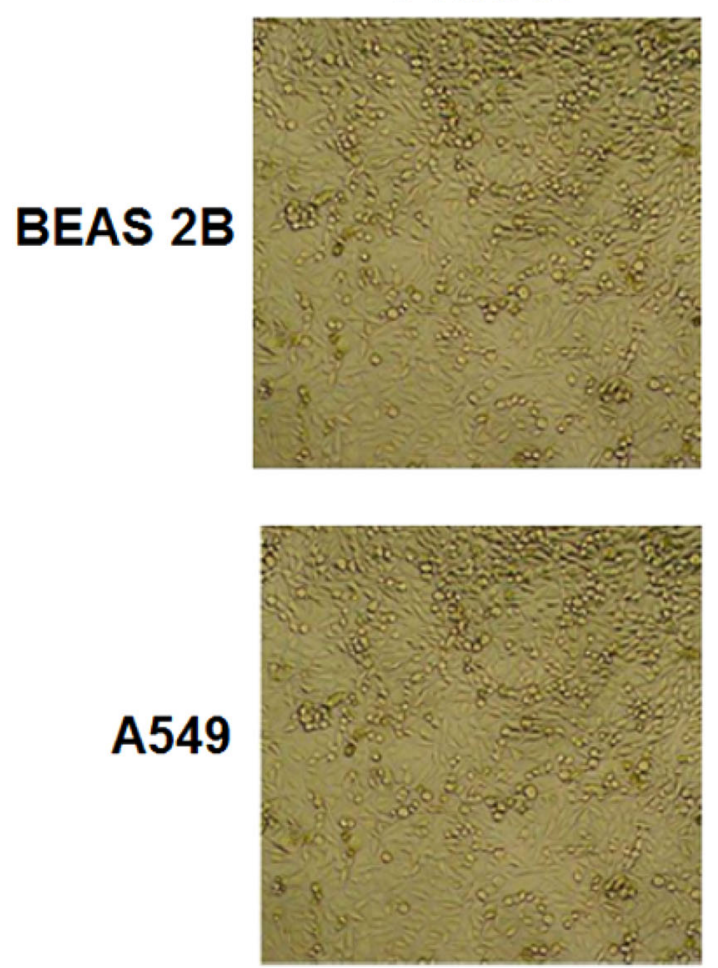

$8 b$
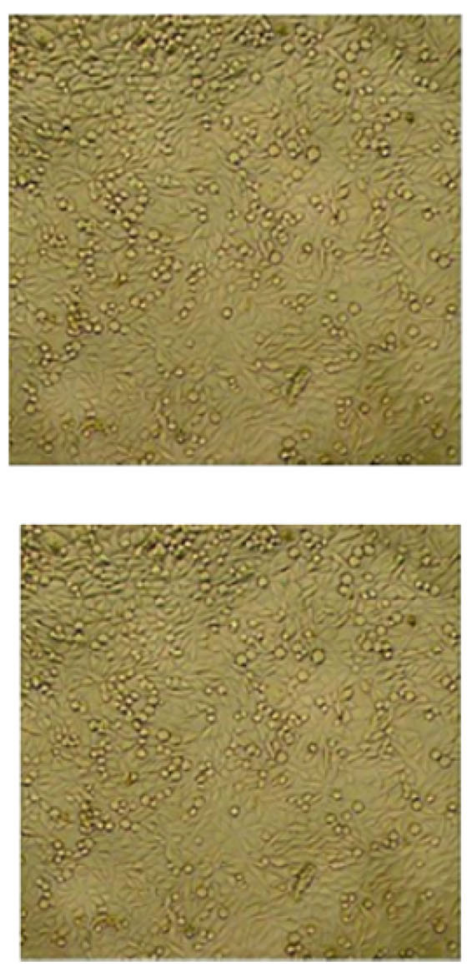

$8 a$
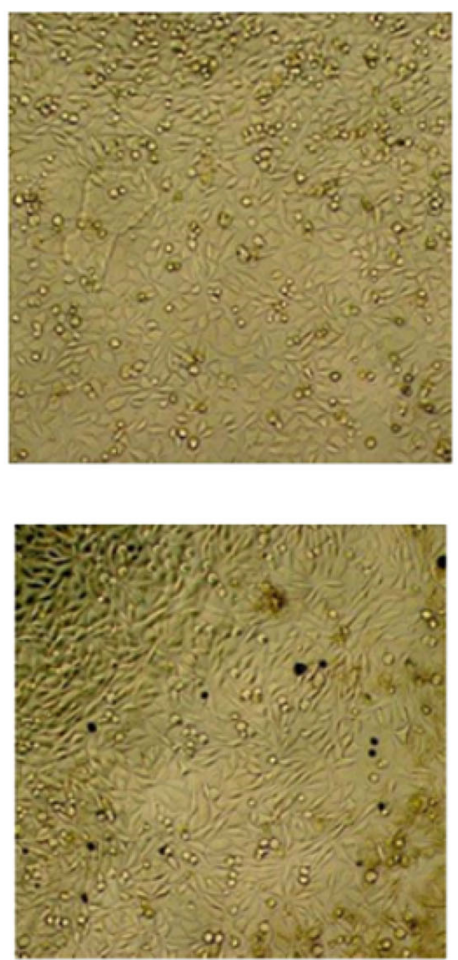

Fig. 4 Optical microscopy images of BEAS $2 \mathrm{~B}$ and A549 cells treated with $10 \mu \mathrm{g} / \mathrm{mL} 8 \mathbf{a}$ and $8 \mathbf{b}$ after $24 \mathrm{~h}$ of incubation at $37{ }^{\circ} \mathrm{C}$

new series of isoindole analogs. Cytotoxic activities of these compounds were then evaluated in two different cancer cell lines, A549 and MCF-7 and one healthy cell line, BEAS 2B. Isoindole analogs, $N$-2-acetoxyetyl $8 \mathbf{a}$ and $N$-Me $\mathbf{8 b}$ displayed cytotoxicity depending on the functional groups on both rings. Compound $8 \mathbf{a}$ was more cytotoxic than $\mathbf{8 b}$ in both cancer cell lines, especially showing a better cytotoxicity against A549 cancer cells. We think that the differences in cytotoxicities may be due to the groups attached to the nitrogen atom because this is the only difference between the two molecules. Thus, we readily see that compound $\mathbf{8 b}$ containing methyl has higher cytotoxicity than compound 8a containing 2-acetoxyetyl. Based on the results of this study, we suggest that the newly synthesized norcantharimide derivatives (8a and $\mathbf{8 b}$ ) might be good potential anticancer agents for the treatment of lung and breast cancer due to their antiproliferative properties in turn having less cytotoxic effect on healthy cells. The cytotoxic properties of compounds $\mathbf{8 a}$ and $\mathbf{8 b}$ should be thoroughly investigated in vivo for possible potential clinical utilization.

Acknowledgements We thank the Biotechnology and Bioengineering Center laboratory staff of Izmir Institute of Technology and Atatürk University (Grant No: 2013/316) for their financial and technical support.
Compliance with ethical standards

Conflict of interest The authors declare no competing interests.

\section{References}

Baran A, Kazaz C, Secen H, Sutbeyaz Y (2003) Synthesis of haloconduritols from an endo-cycloadduct of furan and vinylene carbonate. Tetrahedron 59:3643-3648

Goh YW, Pool BR, White JM (2008) Structural studies on cycloadducts of furan, 2-methoxyfuran, and 5-trimethylsilylcyclopentadiene with maleic anhydride and $\mathrm{N}$-methylmaleimide. J Org Chem 73:151-156

Hart ME, Chamberlin AR, Walkom C, Sakoff JA, McCluskey A (2004) Modified norcantharidins; synthesis, protein phosphatases 1 and $2 \mathrm{~A}$ inhibition, and anticancer activity. Bioorg Med Chem Lett 14:1969-73

Heath WH, Palmieri F, Adams JR, Long BK, Chute J, Holcombe TW, Zieren S, Truitt MJ, White JL, Willson CG (2008) Degradable cross-linkers and strippable imaging materials for step-and-flash imprint lithography. Macromolecules 41:719-726

Hill TA, Stewart SG, Ackland SP, Gilbert J, Sauer B, Sakoff JA, McCluskey A (2007) Norcantharimides, synthesis and anticancer activity: synthesis of new norcantharidin analogues and their anticancer evaluation. Bioorg Med Chem 15:6126-6134

Honkanen RE (1993) Cantharidin, another natural toxin that inhibits the activity of serine/threonine protein phosphatases types 1 and 2A. FEBS Lett 330:283-286

Kok SHL, Chui CH, Lam WS, Chen J, Lau FY, Wong RSM, Cheng GYM, Lai PPS, Leung TWT, Yu MWY, Tang JCO, Chan ASC 
(2007) Synthesis and structure evaluation of a novel cantharimide and its cytotoxicity on SK-Hep1 hepatoma cells. Bioorg Med Chem Lett 17:1155-1159

Kose A, Altundas R, Secen H, Kara Y (2013) Nucleophilic reactivity of ethers against terminal epoxides in the presence of BF3: a mechanistic study. Helv Chim Acta 96:1325-1330

Li YM, Casida JE (1992) Cantharidin-binding protein: identification as protein phosphatase 2A. Proc Natl Acad Sci USA 89: 11867-11870

Li YM, Mackintosh C, Casida JE (1993) Protein phosphatase 2A and its $[3 \mathrm{H}]$ cantharidin/ $[3 \mathrm{H}]$ endothall thioanhydride binding site: inhibitor specificity of cantharidin and ATP analogues. Biochem Pharmacol 46:1435-1443

Lin LH, Huang HS, Lin CC, Lee LW, Lin PY (2004) Effects of cantharidinimides on human carcinoma cells. Chem Pharm Bull $52: 855-857$

Lin PY, Shi SJ, Hsu FL, Chen CF (1998) New cantharidinimides from cantharidin and 2-arylethylamines: efficient synthesis under high pressure. J Chin Chem Soc 45:323-326

Lin PY, Shi SJ, Shu HL, Chen HF, Lin CC, Liu PC, Wang LF (2000) A simple procedure for preparation of $N$-thiazolyl and $N$-thiadiazolylcantharidinimides and evaluation of their cytotoxicities against human hepatocellular carcinoma cells. Bioorg Chem 28:266-272

McCluskey A, Ackland SP, Bowyer MC, Baldwin ML, Garner E, Walkom CC, Sakoff JA (2003) Cantharidin analogues: synthesis and evaluation of growth inhibition in a panel of selected tumour cell lines. Bioorg Chem 31:68-79

McCluskey A, Bowyer MC, Collins E, Sim ATR, Sakoff JA, Baldwin ML (2000) Anhydride modified cantharidin analogues: synthesis, inhibition of protein phosphatases 1 and $2 \mathrm{~A}$ and anticancer activity. Bioorg Med Chem Lett 10:1687-1690
McCluskey A, Walkom C, Bowyer MC, Ackland SP, Gardiner E, Sakoff JA (2001) Cantharimides: a new class of modified cantharidin analogues inhibiting protein phosphatases 1 and $2 \mathrm{~A}$. Bioorg Med Chem Lett 11:2941-2946

Mosmann TJ (1983) Rapid colorimetric assay for cellular growth and survival: application to proliferation and cytotoxicity assays. J Immunol Methods 65:55-63

Nicholls LC, Teare D (1954) Poisoning by cantharidin. Br Med J 2:1384-1386

Robertson MJ, Gordon CP, Gilbert J, McCluskey A, Sakoff JA (2011) Norcantharimide analogues possessing terminal phosphate esters and their anti-cancer activity. Bioorg Med Chem 19:5734-5741

Sakoff JA, Ackland SP, Baldwin ML, Keane MA, McCluskey A (2002) Anticancer activity and protein phosphatase 1 and 2A inhibition of a new generation of cantharidin analogues. Invest New Drugs 20:1-11

Sodeoka M, Baba Y, Kobayashi S, Hirukawa N (1997) Structure-activity relationship of cantharidin derivatives to protein phosphatases 1, 2A1, and 2B. Bioorg Med Chem Lett 7: $1833-1836$

Tagwireyi D, Ball DE, Loga PJ, Moyo S (2000) Cantharidin poisoning due to "Blister beetle" ingestion. Toxicon 38:1865-1869

Tan A, Bozkurt E, Kishali NH, Kara Y (2014) A new and convenient synthesis of amino-phthalimide (1H-Isoindole-1,3(2H)-dione) derivatives and their photoluminescent properties. Helv Chim Acta 97:1107-1114

Tan A, Koc B, Kishali NH, Sahin E, Kara Y (2011) Synthesis of new cantharimide analogues derived from 3 -sulfolene. Synthesis 7 : 1079-1084

Wang GS (1989) Medical uses of mylabris in ancient China and recent studies. J Ethnopharmacol 26:147-162 